\title{
Complementary data on four methods for sampling free-living ticks in the Brazilian Pantanal
}

Dados complementares de quatro métodos para amostragem de carrapatos em vida livre no Pantanal brasileiro

Vanessa do Nascimento Ramos ${ }^{1 *}$; Carolina Fonseca Osava ${ }^{1}$; Ubiratan Piovezan²; Matias Pablo Juan Szabó1

${ }^{1}$ Laboratório de Ixodologia, Faculdade de Medicina Veterinária, Universidade Federal de Uberlândia - UFU, Uberlândia, MG, Brasil

${ }^{2}$ Empresa Brasileira de Pesquisa Agropecuária - Embrapa Pantanal, Corumbá, MS, Brasil

Received August 22, 2014

Accepted October 17, 2014

\begin{abstract}
In this study, four methods for sampling free-living ticks that are used in ecological and human tick-bite risk studies were evaluated. Cloth dragging, carbon dioxide traps and visual searches and inspection of plant litter on the ground were used in field and forest areas within the Brazilian Pantanal. Among the three tick species collected, Amblyomma sculptum predominated, followed by Amblyomma parvum and Amblyomma ovale. Dragging, a cheap and simple technique, yielded the highest numbers of ticks, particularly nymphs. The visual search detected a high number of adult ticks and provided information on tick questing height. Even though laborious, plant litter examination showed that large numbers of ticks may use this stratum. Carbon dioxide $\left(\mathrm{CO}_{2}\right)$ traps are expensive and difficult to handle, but they are highly efficient for adult ticks, especially $A$. parvum. These data indicate that one method alone is incapable of providing a representative sample of the tick fauna in a particular area and that multiple techniques should be used for tick population studies.
\end{abstract}

Keywords: Off-host ticks, collecting techniques, $\mathrm{CO}_{2}$ traps, cloth dragging, visual search, litter inspection.

\section{Resumo}

Neste estudo, foram avaliados quatro métodos de amostragem de carrapatos em vida livre, usados em estudos ecológicos e avaliação do risco de picadas em humanos. Arraste de flanela, armadilhas de gás carbônico $\left(\mathrm{CO}_{2}\right)$, busca visual e inspeção de serrapilheira foram aplicados em áreas campestres e florestais no Pantanal brasileiro. Dentre três espécies coletadas, a predominância foi de Amblyomma sculptum, seguida por Amblyomma parvum e Amblyomma ovale. $\mathrm{O}$ arraste, técnica simples e de baixo custo, resultou em maior número de carrapatos, particularmente de ninfas. A busca visual detectou alto número de carrapatos adultos e forneceu informaçôes sobre altura de espera por hospedeiros. Apesar de trabalhoso, o exame da serrapilheira demonstrou que grande número de carrapatos pode utilizar esse estrato. Armadilhas de $\mathrm{CO}_{2}$ têm custo elevado e são difíceis de manusear, entretanto, são altamente eficientes para carrapatos adultos, em especial para $A$. parvum. Esses dados indicam que somente um método é incapaz de fornecer amostra representativa da ixodofauna em uma área particular e que, para estudos populacionais, técnicas múltiplas devem ser usadas.

Palavras-chave: Carrapatos em vida livre, técnicas de coleta, armadilhas de $\mathrm{CO}_{2}$, arraste de flanela, busca visual, inspeção de serrapilheira.

\section{Introduction}

Ticks spend most of their lifetime off-host (NEEDHAM \& TEEL, 1991). Therefore, studies that evaluate environmental infestation and associated risks to animal and human health are quite relevant. There are several off-host tick sampling methods, but an awareness of their limitations is of paramount importance

*Corresponding author: Vanessa do Nascimento Ramos, Laboratório de Ixodologia, Universidade Federal de Uberlândia - UFU, Avenida Pará, 1720, Campus Umuarama, Bloco 2T, CEP 38400-902, Uberlândia, MG, Brasil, e-mail: vanvanecologia@gmail.com to avoid misleading interpretations. In fact, method efficiency may vary according to environmental characteristics (SZABÓ et al., 2009) and thus should be evaluated in various milieus.

Non-nidicolous host-seeking ticks exhibit at least two strategies for finding hosts. 'Ambush' ticks climb onto vegetation and wait for passing hosts whereas 'hunter' ticks are excited by host signals, leave their shelters and run on the ground towards the host (SONENSHINE et al., 2002). Ambush ticks on vegetation adopt host species-specific questing heights that are related to the size of their preferred animal host (RANDOLPH, 2004; SZABÓ et al., 
2009). Questing behavior varies diurnally and seasonally with climate, overwhelmingly to avoid desiccation (RANDOLPH, 2004). A diapause may also regulate the activity of several species, and ticks may remain quiescent on the ground before the onset of host questing behavior (LABRUNA et al., 2003). Thus, nonnidicolous ticks in a given area may be found at various heights, from the ground up to an elevation of several centimeters on the vegetation, displaying different behavioral activity (questing, rehydrating or diapause). Therefore, ideally, several sampling methods should be used to include as many specimens as possible from the wide array of tick encounter possibilities, and also to avoid bias and misinterpretation of results, in order to gain an understanding of tick and tick-borne disease ecology.

The commonest tick-sampling techniques are dragging (and modifications of this) and carbon dioxide-baited traps. Recently, visual searching has been increasingly used in Brazil (GRAY, 1985; LABRUNA et al., 2005; SZABÓ et al., 2009; TERASSINI et al., 2010). Dragging consists of passing a white cotton flannel over the plant litter on the ground and over the vegetation (ARZUA \& BRESCOVIT, 2006). In visual searches, a trained observer looks for questing ticks on the tips of the leaves along animal trails (TERASSINI et al., 2010). Carbon dioxide traps are systems using a $\mathrm{CO}_{2}$ source over a white surface that are placed on the ground to attract hunter ticks (OLIVEIRA et al., 2000; CANÇADO et al., 2008). Because dragging is convenient and inexpensive, it is the most commonly used method for estimating the abundance of free-living ticks (TACK et al., 2011). However, dragging is useful only for ticks positioned on the surfaces touched by the cotton flannel, especially with regard to ambush ticks. For ticks in non-accessible sites and for hunter and nidicolous ticks, this method is flawed.

Brazil has a tick fauna of 66 species (MARTINS et al., 2014; NAVA et al., 2014) and free-living ticks have been collected in a wide spectrum of environments in different biomes. In these studies, dragging was the method most used for tick collection, followed by $\mathrm{CO}_{2}$ traps (SZABÓ et al., 2007; CANÇADO et al., 2008; OGRZEWALSKA et al., 2009; TOLESANOPASCOLI et al., 2010; VERONEZ et al., 2010; GARCIA et al., 2013; PASCOAL et al., 2013) and, more recently, visual searching in forest environments (LABRUNA et al., 2005; SILVA et al., 2008; SZABÓ et al., 2009). Few evaluations of tick sampling methods in Brazil have been made (TERASSINI et al., 2010; GUEDES et al., 2012). Here, we critically evaluate sampling using four different methods that was undertaken for ecological and human tick-bite risk studies (RAMOS et al., 2014a, b) on ticks within the Brazilian Pantanal region.

\section{Material and Methods}

This study was carried out in Nhecolândia (18 $59^{\prime} 15^{\prime \prime} S$; $\left.56^{\circ} 37^{\prime} 03^{\prime \prime} \mathrm{W}\right)$, a subregion of the Brazilian Pantanal region, located in the state of Mato Grosso do Sul, in an area with high levels of environmental infestation by ticks (RAMOS et al., 2014a), especially Amblyomma sculptum (Berlese, 1888), formerly Amblyomma cajennense (Fabricius,1787) (NAVA et al., 2014). Four methods for tick collection from the environment were used.
Three of the methods were used in the same transects and within the same hour, and one of them at the same location however at another time (CO2 traps) as detailed bellow. For this study, sixteen $40 \mathrm{~m}$-long transects were established in pairs: eight inside forested areas and eight in open fields that were each beside one of the forest fragments. Each transect was sampled twice during the wet season (December 2011 and December 2012) and five times during the dry season (August 2010, June and September 2011 and June and September 2012).

On each sampling occasion, each transect was searched visually, cloth dragging was performed and plant litter on the ground was examined for ticks. Visual searches were performed along both sides of transects, always by the same researcher. For this purpose, the collector walked from one plant to the next, and leaf from all vegetation along all transect were inspected from ground level to one meter above the ground and ticks collected. Time spent for this procedure varied according to the vegetation density along the transect and number of ticks found.

For cloth dragging a cotton flannel ( $1 \mathrm{~m}$ width $\times 2 \mathrm{~m}$ length) was dragged by a slowly walking collector over the transect, a procedure that was done immediately after the visual search. Flannel was carefully inspected for ticks at every 10 meter of dragging.

After visual search and dragging, approximately $2300 \mathrm{~cm}^{3}$ of plant litter (sample $18 \mathrm{~cm}$ long $\times 10 \mathrm{~cm}$ wide $\times 13 \mathrm{~cm}$ deep) was collected at three points in each transect (at $0.0 \mathrm{~m}, 20.0 \mathrm{~m}$ and $40.0 \mathrm{~m}$ ). The litter collected was stored in plastic bags and thoroughly inspected for ticks on a white surface in the laboratory.

Dry ice traps (OLIVEIRA et al., 2000) were used twice in the wet season (February 2012 and February 2013) at the same transect locations and inside four forest fragments. In each forest fragment, five traps were placed on the ground $5 \mathrm{~m}$ apart for one and a half hours. Afterwards each trap and an additional $0.5 \mathrm{~m}$ diameter of the surroundings were meticulously inspected for ticks. In addition, a set of five traps were placed in open fields neighboring three forest fragments.

Ticks were identified as described by Onofrio et al. (2006) and Martins et al. (2010) and voucher specimens were deposited in the Tick Collection of the Federal University of Uberlândia. To provide a gross overview, in spite of bias (by removal of ticks before the dragging, during the visual search), dissimilarities between the tick sampling methods in the transects within forested areas were evaluated using the Kruskal-Wallis test (ZAR, 1999). Since the plant litter samples from the ground in each transect related to only $54 \mathrm{~cm}(3 \times 18 \mathrm{~cm})$ of the $40 \mathrm{~m}$-long transect, the tick numbers are also shown adjusted to the numbers that would have been found in litter covering the entire transect (tick numbers $\times 74$, because $54 \mathrm{~cm} \times 74=39.96 \mathrm{~m}$ ).

\section{Results}

In general, great heterogeneity in tick distribution between the transects was observed. Overall, tick sampling (adults and nymphs) in the transects resulted in finding 763 ticks belonging to three tick species: Amblyomma ovale (Kock, 1844) (n=3); Amblyomma parvum Aragáo, 1908 ( $\mathrm{n}=48)$; and Amblyomma 
sculptum $(\mathrm{n}=712)$. Dragging, visual searches and litter inspection resulted in, respectively, 441 ticks (58\%), 291 (38\%) and 31 (4\%), respectively. Of these, 721 ticks (94\%) were collected in forested areas and $42(6 \%)$ in open fields. The adult and nymph tick numbers collected in the transects by means of dragging, visual searches and litter inspection during both the dry and the wet seasons, for the two most abundant species (A. sculptum and A. parvum) are presented in Tables 1,2 and 3, respectively.

Adults predominated during the wet season and were mainly collected by visual searching, accounting for $86.7 \%$ of the adult ticks in that season. In the dry season, dragging and visual searching resulted in similar numbers of adults, and both were more efficient than litter inspection (Kruskal-Wallis, $\mathrm{H}=13.57$; d.f.=2; $<0.05)$. A. parvum ticks were obtained mainly through visual searching, and during the dry season, but dragging and litter inspection also resulted in several specimens (Tables 1 to 3 ). Adults of $A$. ovale ( $n=3$ specimens) were collected through visual searching and were found in both seasons.

Nymphs predominated in the dry season, and the greatest number of nymphs was collected by means of dragging (KruskalWallis, $\mathrm{H}=51.4$; d.f. $=2 ; \mathrm{p}<0.001$ ), in spite of ticks removal by visual search. Only one nymph (A. sculptum) was found in the wet season (collected through visual searching). Larvae of Amblyomma sp. were recorded solely in the dry season by means of dragging (three clusters), visual searching (one individual) and litter inspection (one individual).

Since the litter inspection results solely came from analysis on $54 \mathrm{~cm}$ along each transect, the tick numbers found were corrected to the entire length of the transects ( 40 meters each). In this case, the number of ticks in the litter would increase from 31 to 2296 . Dry ice traps were used solely in the wet season and resulted in 402 ticks: 311 of $A$. sculptum (median $=26.5 ; 1^{\text {st }}-3^{\text {rd }}$ quartiles $=11.5-65.5$ ) and 90 of $A$. parvum $(2.0 ; 0.0-21.0)$ in the forested areas and only one adult of $A$. sculptum in an open field.

\section{Discussion}

Taking into account the overall numbers of ticks collected in the transects, dragging was the most efficient sampling method. Furthermore, since tick removal by means of visual searching occurred immediately before dragging in the same transect, the efficiency of the latter was underestimated. It is also noteworthy

Table 1. Total numbers, medians, interquartile range $\left(1^{\text {st }}-3^{\text {rd }} \mathrm{Q}\right)$ and minimum $(\mathrm{min})$ - maximum $(\max )$ values per transect for the ticks Amblyomma sculptum (As) and Amblyomma parvum (Ap) collected within forested areas and open fields by means of cloth dragging in the Pantanal region, Nhecolândia, Brazil, in 2011 and 2012.

\begin{tabular}{|c|c|c|c|c|c|c|c|c|}
\hline & \multicolumn{4}{|c|}{ Forest } & \multicolumn{4}{|c|}{ Open field } \\
\hline & \multicolumn{2}{|c|}{ dry } & \multicolumn{2}{|c|}{ wet } & \multicolumn{2}{|c|}{ dry } & \multicolumn{2}{|c|}{ wet } \\
\hline & As & Ap & As & Ap & As & Ap & As & Ap \\
\hline \multicolumn{9}{|l|}{ Adults } \\
\hline Total & 70 & 12 & 8 & 2 & 0 & 2 & 0 & 0 \\
\hline Min-max & $0-24$ & $0-5$ & $0-3$ & $0-1$ & $0-0$ & $0-1$ & $0-0$ & $0-0$ \\
\hline Median & 0 & 0 & 0 & 0 & 0 & 0 & 0 & 0 \\
\hline $1^{\text {st }}-3^{\text {rd }} \mathrm{Q}$ & $0-1$ & $0-0$ & $0-1$ & $0-0$ & $0-0$ & $0-0$ & $0-0$ & $0-0$ \\
\hline \multicolumn{9}{|l|}{ Nymphs } \\
\hline Total & 303 & 5 & 0 & 0 & 37 & 2 & 0 & 0 \\
\hline Min-max & $0-40$ & $0-3$ & $0-0$ & $0-0$ & $0-14$ & $0-1$ & $0-0$ & $0-0$ \\
\hline Median & 6.5 & 0 & 0 & 0 & 0 & 0 & 0 & 0 \\
\hline $1^{\text {st }}-3^{\text {rd }} \mathrm{Q}$ & $3-2.5$ & $0-0$ & $0-0$ & $0-0$ & $0-1$ & $0-0$ & $0-0$ & $0-0$ \\
\hline
\end{tabular}

Table 2. Total numbers, medians, interquartile range $\left(1^{\text {st }}-3^{\text {rd }} \mathrm{Q}\right)$ and minimum $(\min )$ - maximum $(\max )$ values per transect for the ticks Amblyomma sculptum (As) and Amblyomma parvum (Ap) collected within forested areas and open fields by means of visual searches in the Pantanal region, Nhecolândia, Brazil, in 2011 and 2012.

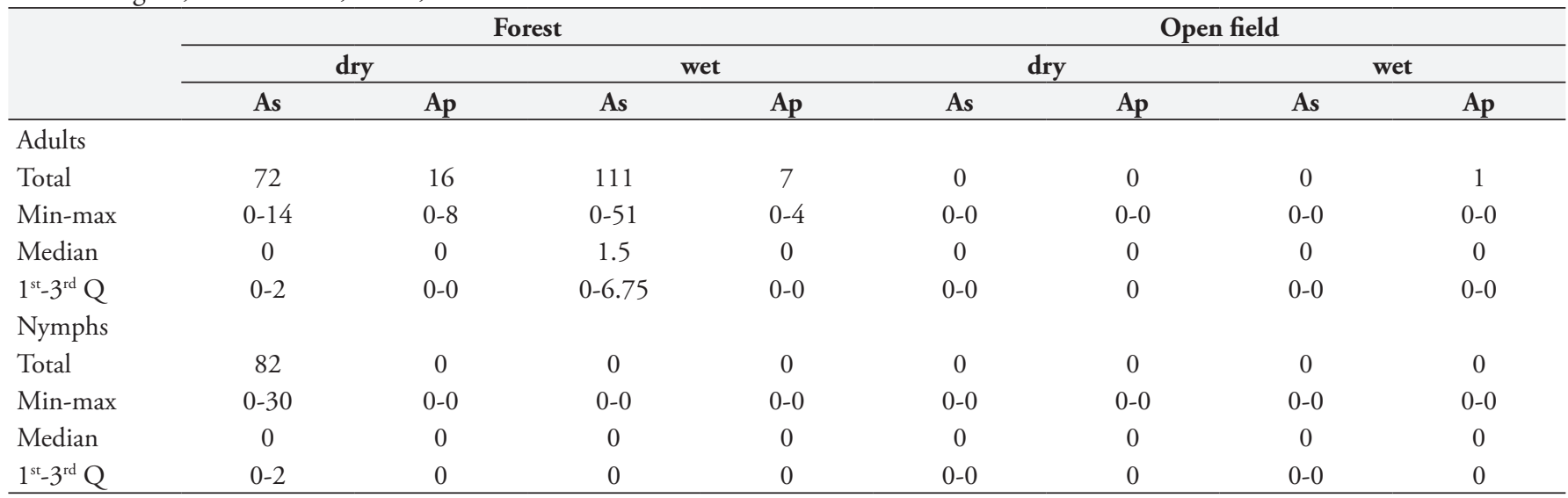


Table 3. Total numbers, medians, interquartile range $\left(1^{\text {st }}-3^{\text {rd }} \mathrm{Q}\right)$ and minimum $(\mathrm{min})$ - maximum (max) values per transect for the ticks Amblyomma sculptum (As) and Amblyomma parvum (Ap) collected within forested areas and open fields from plant litter on the ground in the Pantanal region, Nhecolândia, Brazil, in 2011 and 2012.

\begin{tabular}{|c|c|c|c|c|c|c|c|c|}
\hline & \multicolumn{4}{|c|}{ Forest } & \multicolumn{4}{|c|}{ Open field } \\
\hline & \multicolumn{2}{|c|}{ dry } & \multicolumn{2}{|c|}{ wet } & \multicolumn{2}{|c|}{ dry } & \multicolumn{2}{|c|}{ wet } \\
\hline & As & Ap & As & Ap & As & Ap & As & Ap \\
\hline \multicolumn{9}{|l|}{ Adults } \\
\hline Total & 2 & 0 & 7 & 1 & 0 & 0 & 0 & 1 \\
\hline Min-max & $0-1$ & $0-0$ & $0-6$ & $0-1$ & $0-0$ & $0-1$ & $0-0$ & $0-0$ \\
\hline Median & 0 & 0 & 0 & 0 & 0 & 0 & 0 & 0 \\
\hline $1^{\mathrm{st}}-3^{\mathrm{rd}} \mathrm{Q}$ & $0-0$ & 0 & $0-0$ & $0-0$ & $0-0$ & $0-0$ & $0-0$ & $0-0$ \\
\hline \multicolumn{9}{|l|}{ Nymphs } \\
\hline Total & 20 & 0 & 0 & 0 & 0 & 0 & 0 & 0 \\
\hline Min-max & $0-17$ & $0-0$ & $0-0$ & $0-0$ & $0-0$ & $0-0$ & $0-0$ & $0-0$ \\
\hline Median & 0 & 0 & 0 & 0 & 0 & 0 & 0 & 0 \\
\hline $1^{\text {st }}-3^{\text {rd }} \mathrm{Q}$ & $0-0$ & $0-0$ & $0-0$ & 0 & $0-0$ & 0 & $0-0$ & 0 \\
\hline
\end{tabular}

that most of the adult ticks were already spotted through the visual search, whereas the majority of the nymphs were detected only with the aid of cloth dragging. This is not surprising, given that nymphs are tiny and tend to remain unnoticed in visual inspections. In fact, the efficiency of dragging for collecting nymphs has already been reported (TERASSINI et al., 2010; DANTAS-TORRES et al., 2013; RULISON et al., 2013). However, in spite of the lower efficiency relating to sampling size, visual searching provides valuable information for ecological studies that is missed through dragging. Spotting ticks on the vegetation makes it possible to evaluate location, height and time preferences for questing (SILVA et al., 2008; SZABÓ et al., 2009; GODDARD et al., 2011). In addition, it was curious that $A$. ovale ticks were collected solely through visual inspection.

Plant litter examination was the least productive tick collection method and the one with highest variability among the transects. These observations can be explained by the combined effects of heterogeneous distribution of ticks in the environment and point sampling in the transects. Unfortunately, carrying litter from the whole transect to the laboratory would be impractical and, moreover, inspecting all of this would be excessively time consuming. Nonetheless, the information obtained was valuable: it showed that there is a tick population in the soil stratum in both the forested areas and the field areas of the Brazilian Pantanal region and that this population may be huge. Extrapolating numbers from the small sampled area to the whole length of the transect indicates that the ticks in the plant litter far outnumbered those from the vegetation. Among the various reasons for this, these ticks may have been on the plant litter because they were molting, avoiding desiccation or questing for hosts at the ground level, as is the case with immature forms of several tick species (LANE et al., 1995; SCHULZE et al., 1995; TÄLLEKLINTEISEN \& LANE, 2000).

Direct comparison of the sampling methods in the transects with the $\mathrm{CO}_{2}$ traps is unfeasible in our study because of time and location dissimilarities regarding tick collection. Furthermore, $\mathrm{CO}_{2}$ attracts ticks from an unknown area around the trap. Nonetheless, it is noteworthy that in spite of the relatively low number of traps per fragment (five traps), the number of ticks sampled was higher and more constant than that obtained by the other techniques. Moreover, the number of $A$. parvum adults was doubled with the addition of ticks collected by means of dry ice traps. The behavior of $A$. parvum has not been categorized before, but it displays hunter behavior; even though it is tiny, it is fast and highly mobile. Thus, it is possible to suppose that it was attracted by $\mathrm{CO}_{2}$ from locations unreached by dragging and visual searches. One negative aspect of $\mathrm{CO}_{2}$ traps is their cost and the need for transportation of heavy dry ice before it sublimes away. Alternatively, traps that use other $\mathrm{CO}_{2}$ sources such as the reaction between calcium carbonate and lactic acid (BUTLER et al., 1984; CANÇADO et al., 2008) may be used. It seems that these two kinds of $\mathrm{CO}_{2}$ traps have similar results (GUEDES et al., 2012), but although the alternative $\mathrm{CO}_{2}$ source is cheaper, it still has costs, in that a lot of material has to be carried and setting up each trap is time-consuming.

All the sampling methods overwhelmingly collected A. sculptum, followed by some $A$. parvum specimens and only a few of $A$. ovale. In previous surveys in both environments and on animals from the same location, the same tick species dominated the samples (CAMPOS PEREIRA et al., 2000; CANÇADO et al., 2008; RAMOS et al., 2014a). However, several other tick species have been collected from wild animals as well (CAMPOS PEREIRA et al., 2000). In fact, the four tick collection methods used here are more indicated for hunting and ambush ticks. Nidicolous ticks should be searched for in specific locations such as nests, caves and burrows and/or on animals, and such procedures should be included if a comprehensive study is to be undertaken.

The tick abundance presented high temporal and spatial variation, showing that the distribution of ticks is very heterogeneous. Most of the ticks were found within the forests and, irrespective of the collection method, the most abundant tick species (A. sculptum) displayed a clear seasonal pattern. Adults predominated in the wet season (end of spring and summer) and nymphs and larvae in the dry season (end of fall and winter), as described previously for this species elsewhere in Brazil (SERRA- 
FREIRE, 1982; LABRUNA et al., 2002). Thus, the sampling effort for collecting free-living ticks needs to cover a wide area and, whenever possible, be repeated over time.

Taking all the results together, our data indicate that if only one method used, it is not possible to record a representative sample of the tick fauna in a particular area. As observed by Petry et al. (2010), sampling methodologies depend on differences in behavior, developmental age and microclimate interactions, and multiple techniques should be used for studies on tick population monitoring and community dynamics. In fact, choosing a single technique fulfills specific objectives, and must be directed according to the stage, species, season or habitat that is the focus, in order to avoid sampling bias.

\section{Acknowledgements}

This study was supported by Coordenação de Aperfeiçoamento de Pessoal de Nível Superior - CAPES (scholarship to V.N. Ramos) and Conselho Nacional de Desenvolvimento Científico e Tecnológico - CNPq (Academic Career Research Fellowship to M.P.J. Szabó).

\section{References}

Arzua M, Brescovit AD. Métodos de coleta e preservaçáo para identificação. In: Barros-Battesti DM, Arzua M, Bechara GH, editors. Carrapatos de importância médico-veterinária da regiāo neotropical: um guia ilustrado para identificação de espécies. 1st ed. São Paulo: Vox/ICTTD-3/ Butantan; 2006. p. 183-189.

Butler JF, Holscher KH, Adeyeye O, Gibbs EPJ. Sampling technics for burrow dwelling ticks in reference to potential African swine fever virus vectors. In: Griffths DA, Bowman CE, editors. Acarology VI. Chichester: Ellis Horwood; 1984. vol. 2. p. 1065-1074.

Campos Pereira M, Szabó MP, Bechara GH, Matushima ER, Duarte JM, Rechav Y, et al. Ticks (Acari: Ixodidae) associated with wild animals in the Pantanal region of Brazil. J Med Entomol 2000; 37(6): 979-983. http:// dx.doi.org/10.1603/0022-2585-37.6.979. PMid:11126563

Cançado PHD, Piranda EM, Mourão GM, Faccini JLH. Spatial distribution and impact of cattle-raising on ticks in the Pantanal region of Brazil by using the CO(2) tick trap. Parasitol Res 2008; 103(2): 371 377. http://dx.doi.org/10.1007/s00436-008-0982-8. PMid:18454288

Dantas-Torres F, Lia RP, Capelli G, Otranto D. Efficiency of flagging and dragging for tick collection. Exp Appl Acarol 2013; 61(1): 119-127. http://dx.doi.org/10.1007/s10493-013-9671-0. PMid:23417703

Garcia MV, Silva DC, Almeida RFC, Cunha RC, Matias J, Barros JC, et al. Environmentally associated ticks (Acari: Ixodidae) in Campo Grande, Mato Grosso do Sul, Brazil. Rev Bras Parasitol Vet 2013; 22(1): 124-128. http://dx.doi.org/10.1590/S1984-29612013000100023. PMid:24252958

Guedes E, de Azevedo Prata MC, dos Reis ES, Cançado PHD, Leite RC. Comparative efficiency of two models of $\mathrm{CO} 2$ traps in the collection of free-living stages of ixodides. Parasitol Res 2012; 111(6): 2325-2328. http://dx.doi.org/10.1007/s00436-012-3088-2. PMid:22915273

Goddard J, Varela-Stokes A, Schneider JC. Observations on questing activity of adult Gulf Coast ticks, Amblyomma maculatum Koch (Acari: Ixodidae), in Mississippi, USA. Syst Appl Acarol 2011; 16(3): 195-200.
Gray JS. A carbon dioxide trap for prolonged sampling of Ixodes ricinus L. populations. Exp Appl Acarol 1985; 1(1): 35-44. http://dx.doi. org/10.1007/BF01262198. PMid:3939717

Lane RS, Kleinjan JE, Schoeler GB. Diel activity of nymphal Dermacentor occidentalis and Ixodes pacificus (Acari: Ixodidae) in relation to meteorological factors and host activity periods. J Med Entomol 1995; 32(3): 290-299. PMid:7616519.

Labruna MB, Kasai N, Ferreira F, Faccini JLH, Gennari SM. Seasonal dynamics of ticks (Acari: Ixodidae) on horses in the state of São Paulo, Brazil. Vet Parasitol 2002; 105(1): 65-77. http://dx.doi.org/10.1016/ S0304-4017(01)00649-5. PMid:11879967

Labruna MB, Amaku M, Metzner JA, Pinter A, Ferreira F. Larval behavioral diapause regulates life cycle of Amblyomma cajennense (Acari: Ixodidae) in Southeast Brazil. J Med Entomol 2003; 40(2): 170-178. http://dx.doi.org/10.1603/0022-2585-40.2.170. PMid:12693845

Labruna MB, Camargo LM, Terrassini FA, Ferreira F, Schumaker TS, Camargo EP. Ticks (Acari: Ixodidae) from the state of Rondônia, Western Amazon, Brazil. Syst Appl Acarol 2005; 10(1): 17-32.

Martins TF, Onofrio VC, Barros-Battesti DM, Labruna MB. Nymphs of the genus Amblyomma (Acari: Ixodidae) of Brazil: descriptions, redescriptions, and identification key. Ticks Tick Borne Dis 2010; 1(2): 75-99. http://dx.doi.org/10.1016/j.ttbdis.2010.03.002. PMid:21771514

Martins TF, Venzal JM, Terassini FA, Costa FB, Marcili A, Camargo LM, et al. New tick records from the state of Rondônia, western Amazon, Brazil. Exp ApplAcarol 2014; 62(1): 121-128. http://dx.doi.org/10.1007/ s10493-013-9724-4. PMid:23975565

Nava S, Beati L, Labruna MB, Cáceres AG, Mangold AJ, Guglielmone AA. Reassessment of the taxonomic status of Amblyomma cajennense (Fabricius, 1787) with the description of three new species, Amblyomma tonelliae n. sp., Amblyomma interandinum n. sp. and Amblyomma patinoi n. sp., and reinstatement of Amblyomma mixtum Koch, 1844 and Amblyomma sculptum Berlese, 1888 (Ixodida: Ixodidae). Ticks Tick Borne Dis 2014; 5(3): 252-276. http://dx.doi.org/10.1016/j. ttbdis.2013.11.004. PMid:24556273

Needham GR, Teel PD. Off-host physiological ecology of ixodid ticks. Annu Rev Entomol 1991; 36(1): 659-681. http://dx.doi.org/10.1146/ annurev.en.36.010191.003303. PMid:2006871

Ogrzewalska M, Pacheco RC, Uezu A, Richtzenhain LJ, Ferreira F, Labruna MB. Ticks (Acari: Ixodidae) infesting birds in an Atlantic rain forest region of Brazil. J Med Entomol 2009; 46(5): 1225-1229. http:// dx.doi.org/10.1603/033.046.0534. PMid:19769058

Oliveira PR, Borges LMF, Lopes CML, Leite RC. Population dynamics of the free-living stages of Amblyomma cajennense (Fabricius, 1787) (Acari: ixodidae) on pastures of Pedro Leopoldo, Minas Gerais State, Brazil. Vet Parasitol 2000; 92(4): 295-301. http://dx.doi.org/10.1016/ S0304-4017(00)00322-8. PMid:10996741

Onofrio VC, Labruna MB, Pinter A, Giacomin FG, Barros-Battesti DM. Comentários e chaves para as espécies do gênero Amblyomma. In: Barros-Battesti DM, Arzua M, Bechara GH, editors. Carrapatos de importância médico-veterinária da regiāo neotropical: um guia ilustrado para identificação de espécies. 1st ed. São Paulo: Vox/ICTTD-3/Butantan; 2006. p. 53-71.

Pascoal JO, Amorim MP, Martins MM, Melo C, Silva Júnior ELD, Ogrzewalska M, et al. Ticks on birds in a savanna (Cerrado) reserve on the outskirts of Uberlândia, Minas Gerais, Brazil. Rev Bras Parasitol Vet 2013; 22(1): 46-52. http://dx.doi.org/10.1590/S1984-29612013005000004. PMid:23471429 
Petry WK, Foré SA, Fielden LJ, Kim HJ. A quantitative comparison of two sample methods for collecting Amblyomma americanum and Dermacentor variabilis (Acari: Ixodidae) in Missouri. Exp Appl Acarol 2010; 52(4): 427-438. http://dx.doi.org/10.1007/s10493-010-9373-9. PMid:20585839

Randolph SE. Tick ecology: processes and patterns behind the epidemiological risk posed by ixodid ticks as vectors. Parasitology 2004;129(1): S37-S65. http://dx.doi.org/10.1017/S0031182004004925. PMid:15938504

Ramos VN, Piovezan U, Franco AHA, Osava CF, Herrera HM, Szabó MPJ. Feral pigs as hosts for Amblyomma sculptum (Acari: Ixodidae) populations in the Pantanal, Mato Grosso do Sul, Brazil. Exp ApplAcarol 2014a; 64(3): 393-406. http://dx.doi.org/10.1007/s10493-014-9832-9. PMid:25037743

Ramos VN, Osava CF, Piovezan U, Szabó MP. Ticks on humans in the Pantanal wetlands, Brazil. Ticks Tick Borne Dis 2014b; 5(5): 497-499. http://dx.doi.org/10.1016/j.ttbdis.2014.03.004. PMid:24861806

Rulison EL, Kuczaj I, Pang G, Hickling GJ, Tsao JI, Ginsberg HS. Flagging versus dragging as sampling methods for nymphal Ixodes scapularis (Acari: Ixodidae). J Vector Ecol 2013; 38(1): 163-167. http:// dx.doi.org/10.1111/j.1948-7134.2013.12022.x. PMid:23701621

Serra-Freire NMS. Epidemiologia de Amblyomma cajennense: ocorrência estacional e comportamento dos estádios nâo parasitários em pastagens do Estado do Rio de Janeiro. Arq Univ Fed Rur Rio de 1982; 5(2): 187-193.

Silva BSF, Terassini FA, Coragem JT, Camargo LMA, Labruna MB. Observaçáo e caracterização da altura de carrapatos em arbustos do Parque Natural Municipal de Porto Velho, Amazônia Ocidental-RO. Saber Cientifico 2008; 1(1): 118-131.

Sonenshine DE, Nicholson WL, Lane RS. Ticks (Ixodida). In: Mullen G, Durden L, editors. Medical and veterinary entomology. 1st ed. Amsterdá: Academic Press Elsevier Science; 2002. p. 517-558. http://dx.doi. org/10.1016/B978-012510451-7/50026-8.

Schulze TL, Jordan RA, Hung RW. Suppression of subadult Ixodes scapularis (Acari: Ixodidae) following removal of leaf litter. J Med Entomol 1995; 32(5): 730-733. PMid:7473629.
Szabó MPJ, Castro MB, Ramos HG, Garcia MV, Castagnolli KC, Pinter A, et al. Species diversity and seasonality of free-living ticks (Acari: Ixodidae) in the natural habitat of wild Marsh deer (Blastocerus dichotomus) in Southeastern Brazil. Vet Parasitol 2007; 143(2): 147-154. http://dx.doi.org/10.1016/j.vetpar.2006.08.009. PMid:16962241

Szabó MPJ, Labruna MB, Garcia MV, Pinter A, Castagnolli KC, Pacheco RC, et al. Ecological aspects of the free-living ticks (Acari: Ixodidae) on animal trails within Atlantic rainforest in south-eastern Brazil. Ann Trop Med Parasitol 2009; 103(1): 57-72. http://dx.doi. org/10.1179/136485909X384956. PMid:19173777

Tack W, Madder M, De Frenne P, Vanhellemont M, Gruwez R, Verheyen $\mathrm{K}$. The effects of sampling method and vegetation type on the estimated abundance of Ixodes ricinus ticks in forests. Exp Appl Acarol 2011; 54(3): 285-292. http://dx.doi.org/10.1007/s10493-011-9444-6. PMid:21431925

Tälleklint-Eisen L, Lane RS. Efficiency of drag sampling for estimating population sizes of Ixodes pacificus (Acari: Ixodidae) nymphs in leaf litter. JMed Entomol 2000; 37(3): 484-487. http://dx.doi.org/10.1603/00222585(2000)037[0484:EODSFE]2.0.CO;2. PMid:15535598

Terassini FA, Barbieri FS, Albuquerque S, Szabó MP, Camargo LMA, Labruna MB. Comparison of two methods for collecting free-living ticks in the Amazonian forest. Ticks Tick Borne Dis 2010; 1(4): 194-196. http:// dx.doi.org/10.1016/j.ttbdis.2010.08.002. PMid:21771528

Tolesano-Pascoli GV, Torga K, Franchin AG, Ogrzewalska M, Gerardi $\mathrm{M}$, Olegário MMM, et al. Ticks on birds in a forest fragment of Brazilian cerrado (savanna) in the municipality of Uberlândia, State of Minas Gerais, Brazil. Rev Bras Parasitol Vet 2010; 19(4): 244-248. http://dx.doi. org/10.1590/S1984-29612010000400010. PMid:21184702

Veronez VA, Freitas BZ, Olegário MMM, Carvalho WM, Pascoli GV, Thorga K, et al. Ticks (Acari: Ixodidae) within various phytophysiognomies of a Cerrado reserve in Uberlândia, Minas Gerais, Brazil. Exp Appl Acarol 2010; 50(2): 169-179. http://dx.doi.org/10.1007/s10493-009-9294-7. PMid:19693680

Zar JH. Biostatistical Analysis. 4th ed. New Jersey: Prentice Hall; 1999. 